University of South Carolina

Scholar Commons

$1-2018$

\title{
A Novel Supercritical C02-based Decellularization Method for Maintaining Scaffold Hydration and Mechanical Properties
}

\author{
Michael A. Matthews \\ University of South Carolina - Columbia, matthews@cec.sc.edu \\ Tarek Shazly \\ University of South Carolina \\ Rachel M. Handleton \\ University of South Carolina \\ Dominic M. Casali \\ University of South Carolina
}

Follow this and additional works at: https://scholarcommons.sc.edu/eche_facpub

Part of the Chemical Engineering Commons

\section{Publication Info}

The Journal of Supercritical Fluids, Volume 131, 2018, pages 72-81.

(C) The Journal of Supercritical Fluids, 2018, Elsevier.

Matthews, M.A., Shazly, T., Casali. D.M. \& Handleton, R.M. (2018). A Novel Supercritical CO2-based

Decellularization Method for Maintaining Scaffold Hydration and Mechanical Properties. The Journal of Supercritical Fluids, 131, 72-81.

https://doi.org/10.1016/j.supflu.2017.07.021

This Article is brought to you by the Chemical Engineering, Department of at Scholar Commons. It has been accepted for inclusion in Faculty Publications by an authorized administrator of Scholar Commons. For more information, please contact digres@mailbox.sc.edu. 


\title{
A novel supercritical $\mathrm{CO}_{2}$-based decellularization method for maintaining scaffold hydration and mechanical properties
}

\author{
Dominic M. Casali ${ }^{\mathrm{a}}$, Rachel M. Handleton ${ }^{\mathrm{b}}$, Tarek Shazly ${ }^{\mathrm{b}, \mathrm{c}}$, Michael A. Matthews ${ }^{\mathrm{a}, \mathrm{b}, *}$ \\ a Department of Chemical Engineering, University of South Carolina, Columbia, SC 29208, USA \\ b Biomedical Engineering Program, University of South Carolina, Columbia, SC 29208, USA \\ c Department of Mechanical Engineering, University of South Carolina, Columbia, SC 29208, USA
}

\section{A R T I C L E I N F O}

\section{Keywords:}

Tissue engineering

Decellularization

Supercritical $\mathrm{CO}_{2}$

Aorta

Dehydration

\begin{abstract}
A B S T R A C T
Decellularized tissues are commonly utilized as tissue engineering scaffolds. Decellularization by extended exposure to aqueous detergents can damage the microstructure or deposit cytotoxic residue. Supercritical carbon dioxide $\left(\mathrm{scCO}_{2}\right)$ has been proposed for decellularization, but reportedly causes dehydration and scaffold embrittlement.

Presented herein is a novel decellularization method that preserves matrix hydration state and mechanical properties. Over $97 \%$ of the water in porcine aorta is maintained by presaturating $\mathrm{scCO}_{2}$ with water; however, complete decellularization was not attained by any process utilizing only $\mathrm{scCO}_{2}$. Instead, a novel hybrid method is presented that combines a brief $(48 \mathrm{~h}$ ) exposure of tissue to aqueous detergent, followed by washing with $\mathrm{scCO}_{2}(1 \mathrm{~h})$. The hybrid method fully decellularized the tissue, as confirmed by histology and DNA quantification $(<0.04 \mu \mathrm{g}$ DNA/mg tissue). This hybrid treatment was faster than the standard method (2 days compared to 4-7 days), while preserving tissue structure and mechanical properties.
\end{abstract}

\section{Introduction}

Over 8000 Americans die annually while awaiting an organ transplant, and currently over 120,000 Americans are on the national transplant waiting list. Furthermore, the average transplant wait time is several years [1]. One way to address this problem is the implantation of artificial tissues and organs created by tissue engineering (TE). This could drastically reduce wait times and alleviate the current dearth of available organ donors. However, tissues and organs are extraordinarily nuanced and complicated structures, presenting numerous requirements for creating effective biomimetic materials.

Whether derived from synthetic or natural materials, TE scaffolds must be sterile, porous, mechanically strong, biocompatible, and of appropriate stiffness and surface chemistry for their specific application [2]. Additionally, the scaffold fabrication process may introduce several structural and biochemical deficiencies, including loss of mechanical strength, loss of surface activity, denaturation of extracellular matrix (ECM) proteins, scaffold dehydration, and residual cytotoxicity of some solvents, detergents, and/or crosslinking agents [3]. All of these challenges require continual development of novel and innovative scaffold fabrication methods.

Additionally, TE scaffolds must direct cell proliferation and differentiation during tissue growth. This is a particular strength of naturally-derived biomaterials, which have recently been shown to promote constructive remodeling during tissue growth $[4,5]$. Decellularized ECM has also been shown to elicit an anti-inflammatory immune response, which may be related to a reduced risk of rejection $[6,7]$.

Decellularization is accomplished using a variety of techniques, including physical [8], chemical [9], and enzymatic treatment methods [10]. Treatment with aqueous detergents, such as sodium dodecyl sulfate (SDS), is most common [11,12]. Detergents lyse cell and nuclear membranes, which can lead to thorough cell removal, but also denature proteins and can disrupt glycosaminoglycans (GAGs), growth factors, and ECM ultrastructure [13]. Because of these hazards, it has become common in some tissues, such as blood vessels, to treat with detergents at very low concentrations over multiple days or even weeks, avoiding damage to ECM while eventually removing all cells [14]. Additionally, some decellularization protocols may be relatively brief, but require prolonged wash cycles to remove residual detergent [15]. Though these approaches can be effective, novel methods are desired to decellularize tissues as effectively but with shorter treatment times and without using harsh chemicals or solvents for long periods.

\footnotetext{
* Corresponding author at: 301 Main St. Room 3A03A Columbia, SC 29208, USA.

E-mail address: matthews@cec.sc.edu (M.A. Matthews).
} 
One relatively unexplored method worthy of consideration is using supercritical carbon dioxide $\left(\mathrm{scCO}_{2}\right)$ instead of aqueous- or alcoholbased solvents. $\mathrm{scCO}_{2}$ is non-toxic, non-flammable, and relatively inert; it has desirable solvent properties and a mild critical temperature $\left(31.1{ }^{\circ} \mathrm{C}\right)$, making it viable at physiologic temperatures [16]. Supercritical $\mathrm{CO}_{2}$ has been utilized in numerous biomedical applications, including extraction of biologically relevant molecules $[17,18]$, pasteurization [19-21], and sterilization of synthetic [22-24] and natural biomaterials $[25,26]$. $\mathrm{scCO}_{2}$ has been used extensively to fabricate TE scaffolds from synthetic biomaterials, such as by polymer foaming [27-29], without any significant loss of scaffold bioactivity [30]. Though supercritical drying of natural TE scaffolds has been achieved [31], little research has been undertaken on using $\mathrm{scCO}_{2}$ to fabricate TE scaffolds directly from natural biomaterials, such as by decellularization.

By virtue of its favorable transport properties compared to water, a $\mathrm{scCO}_{2}$ decellularization treatment could offer considerably faster treatment, on the order of hours instead of days. Eliminating detergent use would also reduce damage to the ECM and cytotoxicity associated with residual detergent. In 2008, Sawada et al. presented a study on supercritical $\mathrm{CO}_{2}$ decellularization [32]. They reported adequate DNA and cellular removal, but also extensive extraction of volatile substances during treatment, primarily water [33]. Dehydration caused hardening of the tissue and subsequent scaffold embrittlement, potentially endangering the viability of the scaffold. This raises a significant obstacle to progress in the field.

Other decellularization protocols that utilize ethanol as the decellularization solvent have reported similar tissue dehydration [34], so the observed extraction of water and volatiles during treatment with $\mathrm{scCO}_{2}$ and ethanol is not surprising. In fact, water extraction is very similar to critical point drying, which is commonly used in tissue engineering [35] and other applications, such as electronics processing [36] and scanning electron microscopy [37]. However, for decellularization it is desirable to prevent drying entirely. We hypothesize that tissue dehydration caused by $\mathrm{scCO}_{2}$ treatment can be significantly reduced or even eliminated by presaturating $\mathrm{scCO}_{2}$ with water and other biological volatiles prior to treatment. Validation of this hypothesis is the necessary first step before proceeding to developing a process to decellularize xenogeneic tissue for tissue scaffolds.

Our broad aim is to develop an effective and efficient decellularization method that utilizes $\mathrm{scCO}_{2}$ to reduce treatment time, which will enable further development of $\mathrm{scCO}_{2}$-based tissue engineering and decellularization processes. The objectives of this work are as follows: (1) to demonstrate how to maintain the hydration state of the native tissue in the presence of $\mathrm{scCO}_{2}$, and (2) to present a hybrid $\mathrm{scCO}_{2} /$ detergent treatment that decellularizes the tissue more quickly and as effectively than a standard detergent treatment while maintaining hydration and mechanical properties.

\section{Materials and methods}

\subsection{Apparatus development and validation}

To prevent water extraction from porcine tissue it is necessary to first achieve dynamic thermodynamic equilibrium (i.e. complete saturation) between $\mathrm{scCO}_{2}$ and water. The saturated $\mathrm{scCO}_{2}$ phase is subsequently suitable for treating a TE matrix. The first experimental objective was to ensure that the $\mathrm{sCO}_{2}$ was being fully saturated during the mixing process. Achieving this goal was critical before attempting to decellularize a tissue.

A schematic of the presaturation apparatus is shown in Fig. 1. The apparatus contained valves and fittings rated for high pressures up to 68.9 MPa (2) (High Pressure Co., Erie, PA). Liquid carbon dioxide (1) (bone-dry grade with siphon tube, 99.8\% purity, Praxair Inc., Danbury, CT) was compressed in a chilled syringe pump (3) (500 HP Series, ISCO Inc., Lincoln, NE) and slowly bubbled into the presaturation chamber
(5) (Waters Corp., Milford, MA), where $10 \mathrm{~mL}$ water was previously added. In this chamber $\mathrm{scCO}_{2}$ and the water additive were stirred vigorously until reaching thermodynamic equilibrium (about $15 \mathrm{~min}$ ). At this point, flow was introduced into the $10 \mathrm{~mL}$ treatment chamber (6), which contained the matrix material. Constant flow was maintained by the syringe pump at $1 \mathrm{~mL} / \mathrm{min}$ for the desired treatment time (usually about $1 \mathrm{~h}$ ). At the end of that time, a manually-operated pump (8) (Pressure Generator 62-6-10, High Pressure Equipment Co., Erie, PA) connected to the treatment chamber was used to depressurize the system at a controlled rate of $0.345 \mathrm{MPa} / \mathrm{min}(50 \mathrm{psi} / \mathrm{min}$ ) after treatment.

Validation of the apparatus was demonstrated by using a cold trap to collect dissolved water in the effluent after the back-pressure regulator. Complete thermodynamic equilibrium between $\mathrm{scCO}_{2}$ and water was achieved at flow rates of $5 \mathrm{~mL}$ liquid $\mathrm{CO}_{2} / \mathrm{min}$ and below, as measured at the syringe pump. Validation data are presented in Fig. S1. At flow rates $5 \mathrm{~mL} / \mathrm{min}$ and below, the effluent water mole fractions approach the equilibrium limit. As the flow rate increases, the observed mole fraction decreases, indicating failure to equilibrate. $\mathrm{CO}_{2}$ flow rates of $1 \mathrm{~mL} / \mathrm{min}$ were used for the remainder of this work.

\subsection{Biomaterial selection and preparation}

To further investigate the presaturation hypothesis, we utilized both a synthetic biomaterial (a hydrogel) and a natural tissue, porcine aorta. The hydrogel was poly(acrylic acid-co-acrylamide) potassium salt (Sigma-Aldrich, St. Louis, MO), a hydrogel used previously to establish the ability of $\mathrm{scCO}_{2}$ to achieve sterilization within a porous matrix [22]. Hydrogel powder was hydrated in excess water at $4{ }^{\circ} \mathrm{C}$ for $24 \mathrm{~h}$. Excess water was removed from each hydrogel specimen by light vacuum for 15 min with a Buchner funnel. The hydrogel was next blotted onto a nylon filter and sealed inside the treatment chamber prior to exposure to high pressure $\mathrm{CO}_{2}$. The weight of each gel was approximately $0.2 \mathrm{~g}$.

Porcine aorta was obtained from a local slaughterhouse and the surrounding fatty tissue was removed. The aortic tissue was cut into thin rectangles (approx. $3 \mathrm{~cm} \times 2 \mathrm{~cm}$ ) and stored in phosphate-buffered saline (PBS) at $4{ }^{\circ} \mathrm{C}$ for up to $48 \mathrm{~h}$ prior to use. Each tissue specimen was dried for $15 \mathrm{~min}$ under a light vacuum using filter paper and a Buchner funnel; this removed free saline prior to weighing and treatment. Extensive drying in a vacuum oven $\left(37^{\circ} \mathrm{C}, 38.1 \mathrm{~cm} \mathrm{Hg}\right.$ vacuum) was used as a negative control; changes in tissue mass were recorded after 1, 2, 3, 6, and $24 \mathrm{~h}$. The treatment ratio (i.e. total mass of $\mathrm{CO}_{2}$ per unit mass of hydrated material) and other conditions used (including temperature, pressure, and depressurization rate) were chosen to be analogous to the conditions used by Sawada et al. to allow for comparison [32].

\subsection{Dehydration of model matrix materials}

All treatments were performed using the apparatus shown in Fig. 1. In these tests, a hydrated biomaterial (hydrogel or porcine aorta) was weighed, then treated with either dry $\mathrm{scCO}_{2}$ or presaturated $\mathrm{scCO}_{2}$. After treatment, the biomaterials were weighed again, and changes in mass were recorded. Two treatments were conducted on each biomaterial: one using dry $\mathrm{scCO}_{2}$ (no water in presaturation chamber) and the other using $\mathrm{scCO}_{2}$ presaturated with water. All treatments were performed at $13.8 \mathrm{MPa}(2000 \mathrm{psi})$. The temperature was held constant at either $37^{\circ} \mathrm{C}\left(\rho_{\mathrm{CO} 2}=0.769 \mathrm{~g} / \mathrm{mL}\right)$ or $50{ }^{\circ} \mathrm{C}\left(\rho_{\mathrm{CO} 2}=0.665 \mathrm{~g} / \mathrm{mL}\right.$, for hydrogel only). Four replicate treatments were made at each temperature. All biomaterials, regardless of initial mass, were subjected to a treatment ratio of $60 \mathrm{~min}$ of $\mathrm{scCO}_{2}$ flow per $0.2 \mathrm{~g}$ gel or tissue.

\subsection{Standard decellularization with SDS}

For decellularization studies, porcine aorta was obtained from a local abattoir, rinsed in PBS and cut into ring-shaped sections 


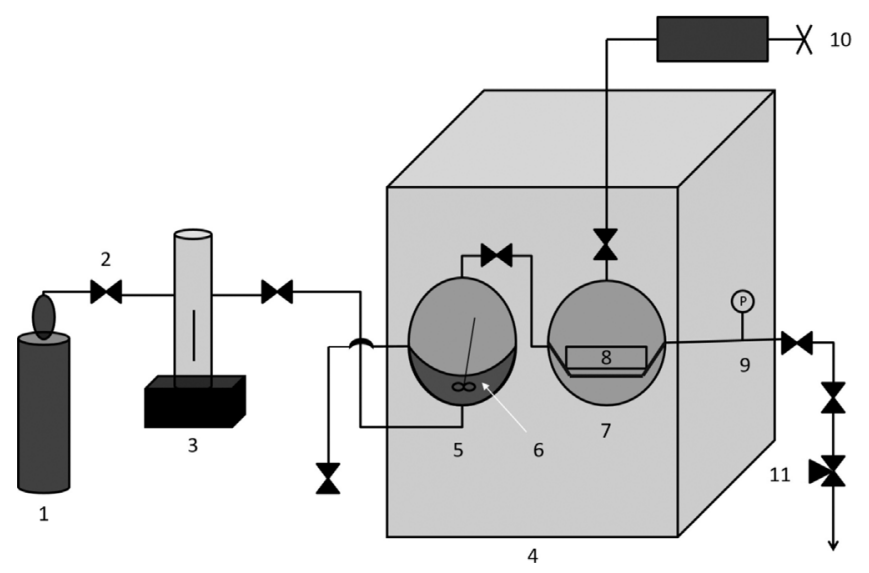

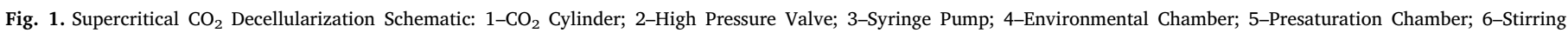
Bar \& Additive(s); 7-Treatment Chamber; 8-Biomaterial; 9-Pressure Gauge; 10-Manual Hand Pump; 11-Back Pressure Regulator.

measuring about $1 \mathrm{~cm}$ in width. At this point, tissues were stored at $-20{ }^{\circ} \mathrm{C}$ until treatment.

The standard SDS treatment followed the protocol of Funamoto et al. [38]. Briefly, tissue was first immersed and agitated for $1 \mathrm{~h}$ in a solution containing $0.2 \%(\mathrm{w} / \mathrm{v})$ EDTA and $10 \mathrm{mM}$ pH 8 Tris buffer to increase cell membrane permeability. It was then decellularized for $48 \mathrm{~h}$ under mild agitation in $0.1 \%(\mathrm{v} / \mathrm{v})$ SDS, $10 \mathrm{mM}$ Tris buffer, $0.2 \mathrm{mg} / \mathrm{mL}$ DNase I, and $0.02 \mathrm{mg} / \mathrm{mL}$ RNase. Matrices were washed with PBS several times over the course of $24 \mathrm{~h}$ to remove cell debris and residual detergent. Thus the total time required for decellularization was at least $72 \mathrm{~h}$.

\subsection{Decellularization with supercritical $\mathrm{CO}_{2}$}

Tissue was loaded into the treatment chamber of the supercritical $\mathrm{CO}_{2}$ apparatus, object (7) on Fig. 1. Liquid carbon dioxide (1) (bone-dry grade with siphon tube, $99.8 \%$ purity, Praxair Inc., Danbury, CT) was compressed in a chilled syringe pump (3) (500 HP Series, ISCO Inc., Lincoln, NE) and slowly bubbled into the presaturation chamber (5) (Waters Corp., Milford, MA) to maximize mass transfer. In this chamber, the additive and $\mathrm{scCO}_{2}$ were stirred vigorously until reaching thermodynamic equilibrium (10-15 min with water and water solutions, 1-2 min for pure ethanol). We used four different solutions in the presaturation chamber in order to determine whether aqueous additives enhanced decellularization: water, water plus Dehypon Ls-54 surfactant (BASF America, Florham Park, NJ), pure ethanol, and a mixture of water and ethanol.

Once equilibrium was reached, the valve to the treatment chamber (7), which contained the porcine aorta (8), was opened, and $\mathrm{CO}_{2}$ flow was programmed to $1 \mathrm{~mL} / \mathrm{min}$ at the pump inlet. During treatment, the environmental chamber (4) (LU-113 model, ESPEC Corp., Osaka, Japan) was used to maintain the temperature at either 10 or $37^{\circ} \mathrm{C}$, and a back-pressure regulator (11) (TESCOM, Elk River, MN) was used to keep the $\mathrm{CO}_{2}$ pressure in the vessels constant at either 10.3 or $27.6 \mathrm{MPa}$ (1500 or $4000 \mathrm{psi}$ ). After the desired exposure time, $\mathrm{CO}_{2}$ flow was stopped and the treatment vessel was isolated. The manual hand pump (10) (Pressure Generator 62-6-10, High Pressure Co.) was used to depressurize the treatment chamber at a rate of $0.34 \mathrm{MPa} / \mathrm{min}(50 \mathrm{psi}$ ) $\min )$.

\subsection{Histology}

After treatment, tissues were fixed in 10\% neutral buffered formalin for at least $24 \mathrm{~h}$ and embedded in paraffin. Tissues were then cut into $5 \mu \mathrm{m}$ sections using a microtome and deparaffinized by immersion in xylene (3 times), 100\% ethanol, 95\% ethanol, $80 \%$ ethanol, and finally water. The tissues were stained with either hematoxylin and eosin or Masson's trichrome stain. A coverslip was mounted on slides, which were then viewed using a light microscope (Nikon E600, Tokyo, Japan) after waiting at least $24 \mathrm{~h}$ for the slides to dry.

\subsection{DNA quantitation}

DNA quantitation was performed with the DNAzol reagent (Invitrogen, Carlsbad, CA) according to the prescribed protocol with minor changes. $25 \mathrm{mg}$ of dry aorta was flash-frozen in liquid nitrogen and ground with a mortar and pestle. It was then placed in a $2 \mathrm{~mL}$ tissue homogenizer (VWR International, Radnor, PA) with $0.5 \mathrm{~mL}$ of DNAzol reagent and ground for about 10 strokes or until fully dissolved. The solution was centrifuged at $10,000 \times g$ for $10 \mathrm{~min}$ and the supernatant was recovered. $0.25 \mathrm{~mL}$ of $100 \%$ ethanol was added to precipitate the DNA, which was recovered and washed twice with $70 \%$ ethanol for $1 \mathrm{~min}$ per wash. DNA was next air-dried for $5 \mathrm{~s}$ and dissolved in a sodium hydroxide solution ( $\mathrm{pH}$ 9). Absorbance at $260 \mathrm{~nm}$ was recorded using a spectrophotometer (DU 730 model, Beckman-Coulter, Brea, CA) and the DNA concentration was calculated based on the absorbance measurement and initial mass of the tissue.

\subsection{Hybrid $\mathrm{SDS} / \mathrm{CO}_{2}$ treatment}

The hybrid treatment included exposure of tissue to the standard detergent solution for $48 \mathrm{~h}$, as performed in Section 2.4, followed by $\mathrm{scCO}_{2}$ treatment for $1 \mathrm{~h}$ as described in Section 2.5, using the solution of water and ethanol to presaturate the $\mathrm{scCO}_{2}$. The hybrid treatment is discussed in greater detail in Section 3.3.

\subsection{Uniaxial ring test}

The mechanical response of aortic ring specimens following three selected treatments was examined using a uniaxial ring test as previously described [39]. The treatments studied were standard SDS treatment (Section 2.4), treatment with $\mathrm{scCO}_{2}$ and added ethanol (Section 2.5), and the hybrid $\mathrm{SDS} / \mathrm{sCCO}_{2}$ treatment (Section 2.8). Briefly, aortic rings (thickness $3-4 \mathrm{~mm}$, diameter $10-15 \mathrm{~mm}$ ) were mounted onto a Bose Electroforce 3230 Biomechanical Tester (Bose Corp., Farmingham, MA) using two parallel cannulas. Specimens were subjected to three preconditioning cycles at a rate of $0.05 \mathrm{~mm} / \mathrm{s}$ with a maximum stretch ratio, $\lambda$, of 1.2 during each cycle. Samples were kept hydrated with PBS during preconditioning to prevent dehydration. At the start of the fourth cycle, load and displacement data were recorded at a rate of 50 points/sec using the accompanying Wintest software. An exponential regression model was fit to the response of each aortic 
specimen. The Cauchy stress at $\lambda=1.1$ was computed based on each regression and used as the response variable for comparison among treatments.

\subsection{SDS quantitation}

Residual SDS from the standard and hybrid treatments was quantified using an SDS Detection and Estimation Kit (G Biosciences, St. Louis, MO). The assay involves mixing $1 \mathrm{~mL}$ methylene blue dye with $0.5 \mathrm{~mL}$ extraction buffer and $5 \mu \mathrm{L}$ of aqueous solution containing SDS, then vortexing for $30 \mathrm{~s} .1 \mathrm{~mL}$ of chloroform was added, then the mixture was vortexed again for $30 \mathrm{~s}$. Methylene blue is extracted into the organic phase if SDS is present. After waiting $5 \mathrm{~min}$, the bottom organic phase was sampled and optical density was measured at $600 \mathrm{~nm}$. SDS concentration was calculated by comparison to a standard curve.

\subsection{Statistical analysis}

Numerical data are presented as mean values plus or minus one standard deviation. A Student's $t$-test was used to analyze confidence in statistical differences between groups. 95\% confidence $(p<0.05)$ was considered to be statistically significant, while $99 \%$ confidence $(p<0.01)$ was considered highly significant.

\section{Results and discussion}

\subsection{Dehydration of matrix materials}

Hydrogels were treated with dry (control) and presaturated supercritical $\mathrm{CO}_{2}$ at 37 and $50{ }^{\circ} \mathrm{C}$ and at $13.8 \mathrm{MPa}(2000 \mathrm{psi})$; porcine aorta was treated at $37^{\circ} \mathrm{C}$ only. Data from these experiments are summarized in Fig. 2. For hydrogels at both temperatures, the average water retention was about $50 \%$ for dry $\mathrm{scCO}_{2}$, and just over $99 \%$ with presaturated $\mathrm{scCO}_{2}$. The differences in mean water retention at both temperatures were highly significant.

These observations with the hydrogel confirm the initial hypothesis. The control trials with dry $\mathrm{scCO}_{2}$ showed significant dehydration of the hydrogels caused by extraction of water. This resulted in about a $50 \%$ average mass loss. The large error bars for hydrogels result from the variation in drying rate and surface tension effects as the hydrogel structure collapses [40]. Water retention in the gel is slightly less at $50{ }^{\circ} \mathrm{C}$ than at $37^{\circ} \mathrm{C}$, likely because both water vapor pressure and solubility in $\mathrm{scCO}_{2}$ increase with temperature. On the other hand, presaturating $\mathrm{scCO}_{2}$ gave little to no water extraction; as over $99 \%$ of the initial mass is maintained at both temperatures, confirming the initial hypothesis.

Results for dry and presaturated $\mathrm{scCO}_{2}$ treatments of porcine aorta are also shown in Fig. 2. The average mass retention is $78.6 \% \pm 4.6 \%$ with dry $\mathrm{CO}_{2}$ and $97.3 \% \pm 1.4 \%$ with presaturated $\mathrm{scCO}_{2}$; this difference is highly significant. It is evident from these results that using presaturated $\mathrm{scCO}_{2}$ considerably reduces the amount of mass lost during treatment, again confirming the initial hypothesis. However, both the presaturated $\mathrm{scCO}_{2}$ and vacuum drying data suggest that a small amount (about $2-3 \%$ of total mass) of substances other than water are extracted from the tissue. While the aorta is primarily composed of water and $\mathrm{CO}_{2}$-insoluble proteins like elastin and collagen, porcine aorta also contains small amounts of lipids, such as cholesterol [33]; these may comprise the remaining extracted substances in the tissue, as $\mathrm{scCO}_{2}$ has been proven efficacious for the extraction of fatty acids and other lipids [41]. An analogous technique to maintain these volatiles may be possible, though further research is needed to confirm this.

Vacuum drying was used to produce a complete drying curve for porcine aorta tissue $(n=6)$, as shown in Fig. S2. The circle and square indicate where dry and presaturated $\mathrm{scCO}_{2}$ treatments like on the drying curve, respectively. This comparison shows that even dry $\mathrm{scCO}_{2}$ treatment causes much less drying than the vacuum treatment over the same time interval. This is also evident visually, as vacuum drying caused tissues to darken significantly and become more brittle than those treated with $\mathrm{scCO}_{2}$.

\subsection{Decellularization with supercritical $\mathrm{CO}_{2}$}

With a method of preventing tissue dehydration now established, we focused on decellularizing a tissue. The objective of decellularization is to maximize removal of cells and cellular debris while minimizing ECM alteration [42]. Ideally, a $\mathrm{scCO}_{2}$-based decellularization treatment would speed up the process compared to protocols that require weeks-long wash steps, while using a benign solvent that leaves no residual material in the matrix.

Currently, there is no universally-accepted standard for evaluating the extent of decellularization. This is not surprising, because tissues vary greatly in stiffness, cell density, ECM composition, and numerous other characteristics, so decellularization processes must be tailored to the specific tissue of interest [43]. However, Crapo et al. recently proposed a list of three criteria that can adequately describe a decellularized tissue of any kind [42]. They are:

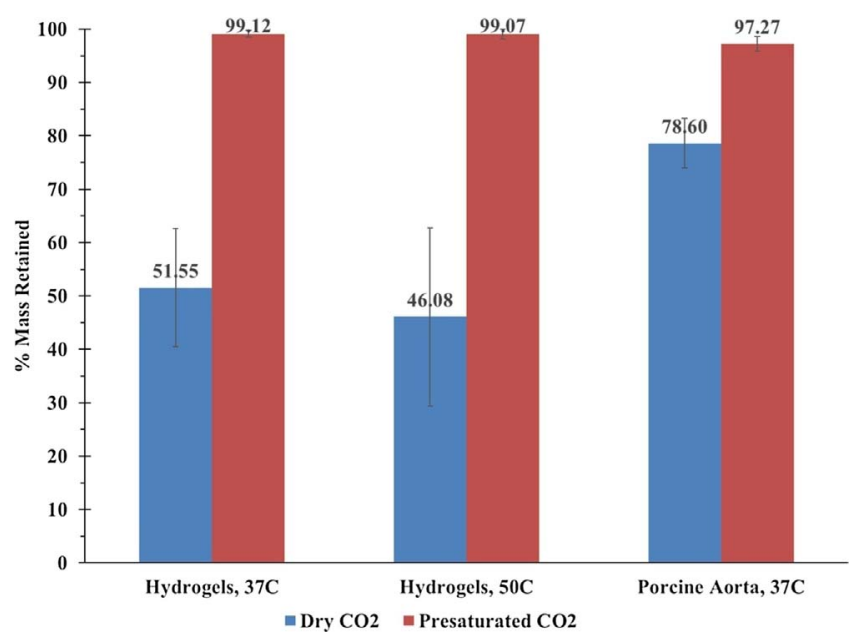

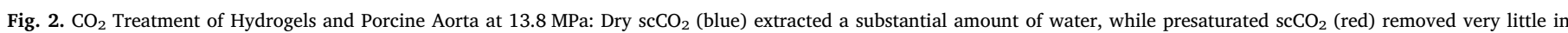

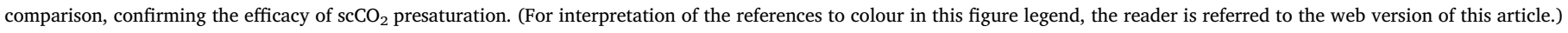


1. Lack of visible nuclear material in H \& E or DAPI-stained sections

2. Total amount of double-stranded DNA less than $50 \mathrm{ng}(0.05 \mu \mathrm{g}) / \mathrm{mg}$ dry tissue

3. No individual DNA fragment longer than 200 base pairs

In this study, we focused on the first two criteria by performing $\mathrm{H} \& \mathrm{E}$ staining and DNA quantitation on porcine aorta after treatment, as these are more commonly performed and allow for direct comparison to the results of Sawada and others [32].

Six different treatments of porcine aorta were undertaken, and the extent of decellularization for each was evaluated using histology and DNA quantification. The treatments were two controls - standard SDS treatment and treatment with dry $\mathrm{scCO}_{2}$-and treatment with $\mathrm{scCO}_{2}$ presaturated with four different liquids: pure water, water $+\mathrm{Ls}-54$, pure ethanol, and water + ethanol. The $\mathrm{scCO}_{2}$ treatments were performed at $37^{\circ} \mathrm{C}$ and $27.6 \mathrm{MPa}\left(\rho_{\mathrm{CO} 2}=0.908 \mathrm{~g} / \mathrm{mL}\right)$ for about $1 \mathrm{~h}$ with a $0.34 \mathrm{MPa} / \mathrm{min}$ depressurization rate; these conditions were chosen based on the factorial design and process optimization presented in Sawada's work [32].

Tissue sections from each treatment were stained with hematoxylin and eosin (H \& E) and observed under an optical microscope. Sections from the tunica media of each of the controls can be seen in Fig. 3a-c at $40 \times$ magnification. In the native tissue (image a on the figure), intact smooth muscle cells can be readily observed. The elastic fibers of the ECM are in a parallel orientation with fairly regular spacing. Image (b) on the figure shows the tissue after treatment with SDS and PBS washing. Dark, irregularly-shaped areas of cellular debris are observed, indicating partial decellularization but incomplete cell removal. Additionally, significant damage to the ECM fibers is evident based on their widespread breakage and deformation. Tissues treated with dry $\mathrm{scCO}_{2}$ (image c) primarily have intact, undisturbed cells compared to the native tissue, though a minority of cells appear to be shriveled or completely removed based on the increased white space in the micrographs. Elastic fibers are disturbed somewhat, as some shrinkage is observed and the spacing between fibers is less uniform, but unlike the SDS treatment, the fibers are not broken entirely.

These findings can be explained by considering the known mechanisms of how detergents and supercritical fluids interact with cells and proteins. The SDS results mirror the literature [44,45]; it is wellknown that most ionic detergents, including SDS, disrupt both the cell and nuclear membranes by replacing molecules in the lipid bilayer via the micelle effect [13]. This effect leads to intracellular contents exiting the confines of the cell and leaving the black, irregular regions of cellular debris found in the micrographs. However, SDS alone will not remove the cellular debris from the matrix; debris removal is usually accomplished by a subsequent step of prolonged washing with a saline solution. In this work, a relatively brief $24 \mathrm{~h}$ PBS wash was performed according to Funamoto's protocol [38], but others have shown that saline rinses often require several days or even weeks to remove all residual cellular material and detergent from a decellularized tissue [14]. It is also well-documented that SDS denatures proteins, so the heavy disruption of the elastic fibers is not surprising [13].

On the other hand, treatment with dry $\mathrm{scCO}_{2}$ was not nearly as disruptive to elastic fibers in the ECM. Though no breakage was observed, there is still a clear loss of uniformity in both fiber size and spacing. This is a reasonable outcome, given that tissue dehydration is a known side effect of treatment with dry $\mathrm{scCO}_{2}$. However, $\mathrm{scCO}_{2}$ was ineffective at removing cells from the matrix. This outcome matches previous observations by Sawada's group that $\mathrm{scCO}_{2}$ is ineffective at cell removal without an additive [32]. Though there is currently a clear lack of experimental proof, $\mathrm{scCO}_{2}$ has been proposed to remove cells or cellular debris from a matrix by supercritical extraction [42]. Because cellular materials are charged, dissolution in pure $\mathrm{scCO}_{2}$ is minimal because carbon dioxide is a completely nonpolar molecule. This suggests using a polar, $\mathrm{CO}_{2}$-soluble additive to aid in decellularization, as described in the following.
Four different additives were used to pre-saturate $\mathrm{scCO}_{2}$ in an attempt to improve cell removal: water (A), water plus Ls-54 (B), ethanol (C), and water plus ethanol (D). H \& E sections from treatments A and B are shown in Fig. 3d and e. The results are not noticeably different from those with dry $\mathrm{scCO}_{2}$, Fig. 3c. With regard to decellularization, there appears to be no more effectiveness than with dry $\mathrm{scCO}_{2}$. This is not surprising, because although water is polar, it has relatively low solubility in supercritical $\mathrm{CO}_{2}$ [46], meaning that the humidified $\mathrm{scCO}_{2}$ still is highly nonpolar and is unlikely to be able to extract cells; this agrees with the findings of Sawada et al. Using water as an additive does appear to improve the continuity and uniformity of elastic fibers, which makes sense because the tissue is not dehydrated by this particular treatment.

Fig. 3e shows the effect of adding Ls-54 to the solution to be minimal. Ls-54 is a non-fluorinated surfactant that has been shown in the past to have solubility in supercritical $\mathrm{CO}_{2}$ and to be an effective $\mathrm{scCO}_{2}$ additive for removing bacterial endotoxin from a solid surface $[47,48]$. However, it appears to be ineffective in enhancing decellularizaton, probably because of its dissimilar chemistry compared to SDS. Additionally, Ls-54 has low solubility in $\mathrm{scCO}_{2}$ at physiologic temperature and is more soluble liquid $\mathrm{CO}_{2}$ [49]. Therefore, the $\mathrm{scCO}_{2}$ / water/Ls-54 treatment was also conducted at $10^{\circ} \mathrm{C}$, but no significant changes in extent of decellularization were observed.

To further increase the polarity of the $\mathrm{scCO}_{2}$ mixture, two final treatments were investigated, where ethanol or water + ethanol were the additives. $\mathrm{H} \& \mathrm{E}$ stained sections from these treatments are shown in Fig. $3 \mathrm{f}$ and $3 \mathrm{~g}$. Treatment with ethanol as the additive shows considerable shriveling and branching of the elastic fibers, as expected. However, the use of ethanol does not aid considerably in cell removal. Though some of the areas where the ECM is damaged have fewer cells, the intact elastic fibers have numerous intact cells attached to them. The addition of water to the ethanol does not markedly affect the extent of decellularization, but does significantly improve the condition of the elastic fibers. This finding is expected based on Fig. $3 \mathrm{~d}$ and e, as well as the earlier part of this work; the primary objective of using water as an additive is to prevent dehydration, not to remove cells.

Overall, the three treatments that included water as an additive were notably more effective in maintaining the morphology and alignment of the elastic fibers. This supports the findings presented earlier, which showed that presaturating $\mathrm{scCO}_{2}$ with water before contacting the tissue prevents dehydration of the extracellular matrix during $\mathrm{scCO}_{2}$ treatment, whereas dehydration was observed when ethanol was the only additive. Though interesting, the prevention of tissue dehydration is made impractical by the lack of cellular removal in any of the experiments.

Ultimately, microscopy indicates only very limited cell removal with the four $\mathrm{scCO}_{2}+$ additive treatments, and not nearly enough to indicate decellularization. To confirm visual microscopy results, we employed quantification of DNA as a measure of decellularization; one of the proposed criteria for establishing decellularization is a doublestranded DNA concentration below $0.05 \mu \mathrm{g}$ DNA/mg dry tissue [42]. For each treatment in this study, DNA was extracted and its concentration was calculated based on spectrophotometric absorbance readings. Results of DNA quantification are shown in Fig. 4. All treatments show some amount of DNA removal compared to the untreated tissue. However, none of the $\mathrm{scCO}_{2}$ treatments approach the target maximum concentration of $0.05 \mu \mathrm{g}$ DNA/mg dry tissue.

The DNA results follow the histological findings, where SDS was required in some capacity to rupture cell membranes and attain at least an appreciable amount of cell removal. The four $\mathrm{scCO}_{2}$ additives do reduce the DNA content compared to the untreated tissue, though none of the treatments approach complete decellularization, as with the $\mathrm{H} \& \mathrm{E}$ findings. The use of ethanol also appears to have the most significant effect on DNA removal compared to $\mathrm{scCO}_{2}$ with just water or water and Ls-54. However, this is negated by significant dehydration and structural damage as noted above. 


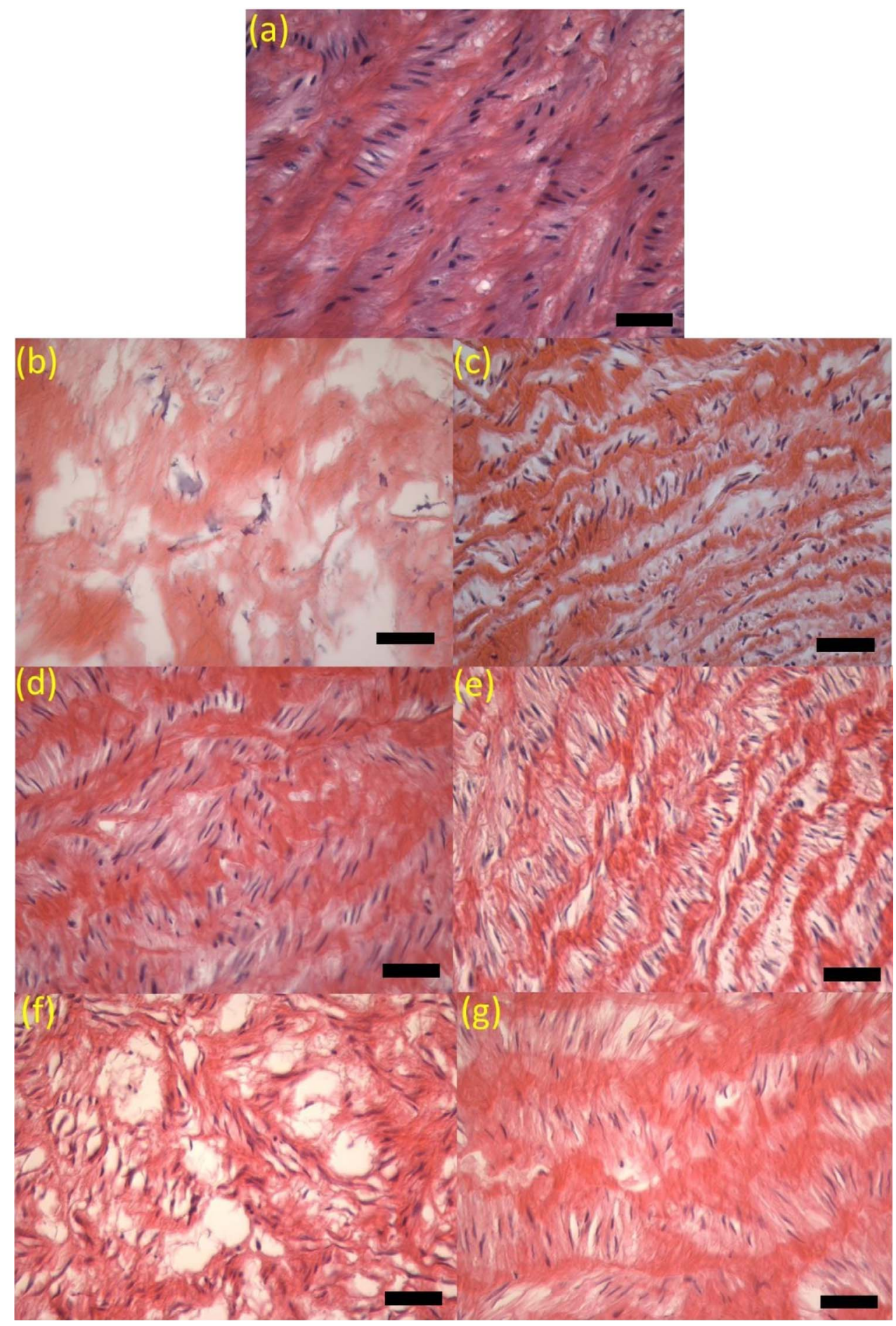

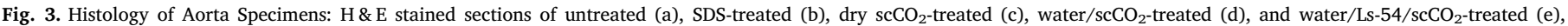
ethanol $/ \mathrm{scCO}_{2}$-treated (f), and ethanol/water $/ \mathrm{scCO}_{2}$-treated $(\mathrm{g})$ porcine aorta. Scale bars represent $50 \mu \mathrm{m}$.

The failure of the $\mathrm{scCO}_{2}$ /ethanol mixture to decellularize is the most surprising result, given that this finding contrasts with the findings of Sawada's group and that the experiments and the apparatuses used in both studies are each very similar. This led us to consider the mechanisms of $\mathrm{scCO}_{2}$ decellularization proposed by Sawada in more detail.

\subsection{Hybrid $\mathrm{SDS} / \mathrm{scCO}_{2}$ decellularization}

The limited discussion in the literature for supercritical $\mathrm{CO}_{2}$ decellularization proposes two possible mechanisms: supercritical extraction of cells or cellular debris as a primary mechanism, and physical dislodging of cells from the ECM caused by high pressure. Based on the current findings, we do not expect the high pressure alone to remove cells; other work has been published where blood vessels have been decellularized with high hydrostatic pressure - pressures on the order of several hundred MPa - and cells still require long-term continuous washing to be removed in these applications [38].

This suggests renewed focus on the extraction mechanism. In the previous section, the ineffectiveness of Ls- 54 surfactant in decellularization was discussed, possibly because of its inability to permeate the cell membrane. We theorized that $\mathrm{scCO}_{2}$ in general may suffer from this 


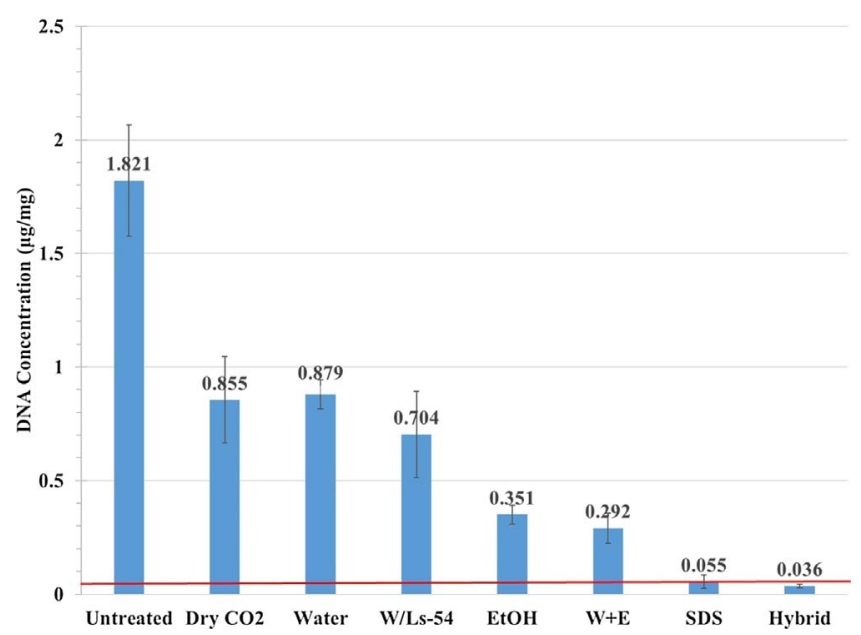

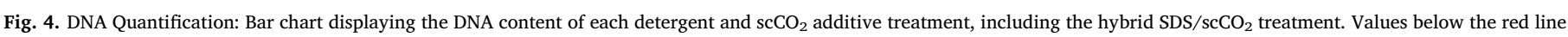

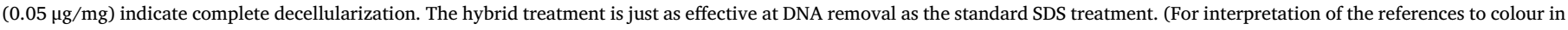
this figure legend, the reader is referred to the web version of this article.)

same problem. To test this hypothesis, a two-step hybrid SDS $/ \mathrm{scCO}_{2}$ decellularization treatment was investigated. With this treatment, tissues were treated with SDS as described in Section 2.4, but without the subsequent PBS wash. Instead, tissues were then treated (washed) for $1 \mathrm{~h}$ with supercritical $\mathrm{CO}_{2}$ that was presaturated with ethanol and water at the same thermodynamic conditions used previously.

The effect of the hybrid treatment can be seen in Fig. 5. Using this hybrid approach, there are no visible intact cells or cellular debris. Therefore, it is likely that the tissue is fully decellularized. This is an exciting and intriguing result that suggests supercritical $\mathrm{CO}_{2}$ with polar additives will extract intracellular debris, but will not quickly penetrate the cell membrane to do so unless another agent is used to enhance membrane lysis. Significantly, the ECM fibers appear to be intact and mostly undisturbed compared to the standard SDS treatment. Maintenance of fiber integrity may be a result of faster SDS removal; the $\mathrm{scCO}_{2}$ "wash" takes only an hour instead of the day or more required for the standard PBS wash.

The intact state of elastic fibers in the ECM observed in Fig. $5 \mathrm{c}$ suggests that the hybrid treatment may remove residual SDS; if substantial SDS remained in the matrix, it would denature the fibers as observed with other SDS treatments. Cytotoxicity is also observed for many cell types at residual SDS concentrations greater than about $0.002 \%$ [50]. An SDS detection assay was used to confirm this hypothesis; results are shown in Fig. 6. Residual SDS was quantified for the standard SDS treatment and the SDS $/ \mathrm{sCCO}_{2}$ hybrid treatment. The figure shows that one hour of $\mathrm{scCO}_{2}$ treatment removes about as much SDS as $24 \mathrm{~h}$ of washing with PBS, a significant time savings. PBS washes also have diminishing returns, requiring washing for several days in many cases to reduce SDS below cytotoxic levels [51]. Thus, $\mathrm{scCO}_{2}$ could compare even more favorably over longer time periods. This finding also indicates some degrees of solubility of SDS in the $\mathrm{scCO}_{2}$ treatment solution. Solubility is likely low given that SDS is a charged, polar species, but the concentration of residual SDS is quite low initially, and some solubility in $\mathrm{scCO}_{2}$ is expected given the presence of added ethanol and that SDS is an organic molecule with relatively low molecular weight, similar to caffeine [52].

Decellularization was verified by DNA quantitation for the hybrid method, which can be viewed in Fig. 4 along with the earlier treatments. The figure shows a level of DNA removal similar to the standard SDS treatment, below the threshold for decellularization with a concentration of $0.036 \mu \mathrm{gNA} / \mathrm{mg}$ dry tissue. This is a very exciting result, as the hybrid method is able to achieve the original objective: to decellularize effectively while avoiding dehydration of the tissue.

It should be noted that the DNA test performed has sensitivity limitations with the spectrophotometer used. Optical density near the decellularization threshold is very low, approaching the tolerance of the instrument. Thus, some error may exist in the numerical value of the DNA concentration for SDS-containing treatments. However, the histological results and statistical comparison to the other treatments confirm the efficacy of the hybrid method.

A uniaxial ring test was used as a preliminary method to evaluate the mechanical response of aorta following three select decellularization protocols: standard SDS treatment, treatment with $\mathrm{scCO}_{2}$ and ethanol additive, and hybrid $\mathrm{SDS} / \mathrm{scCO}_{2}$ treatment. Vascular tissue nominally exhibits a nonlinear stress-strain relationship under this testing modality [53], which was qualitatively compromised by treatment with $\mathrm{scCO}_{2}$ and ethanol (highly linear response) but retained following the other examined protocols (Supplemental Fig. S3).

The computed stress values (Table 1) and the overall shape of the stress-strain curves suggests that SDS exposure reduces construct

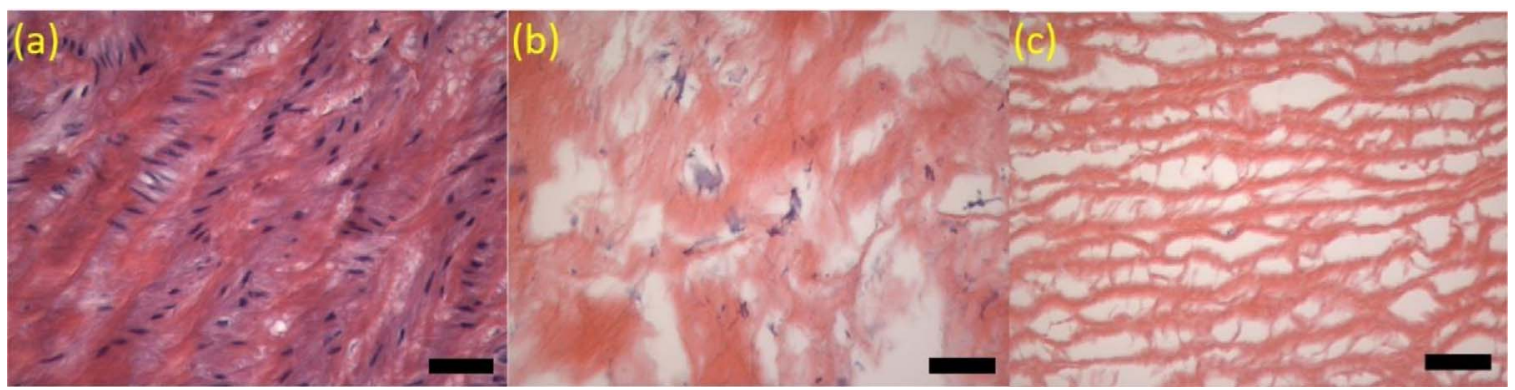

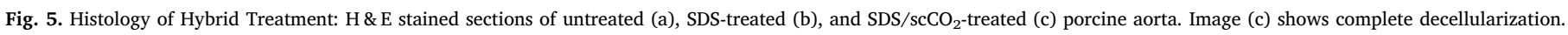
Scale bars represent $50 \mu \mathrm{m}$. 


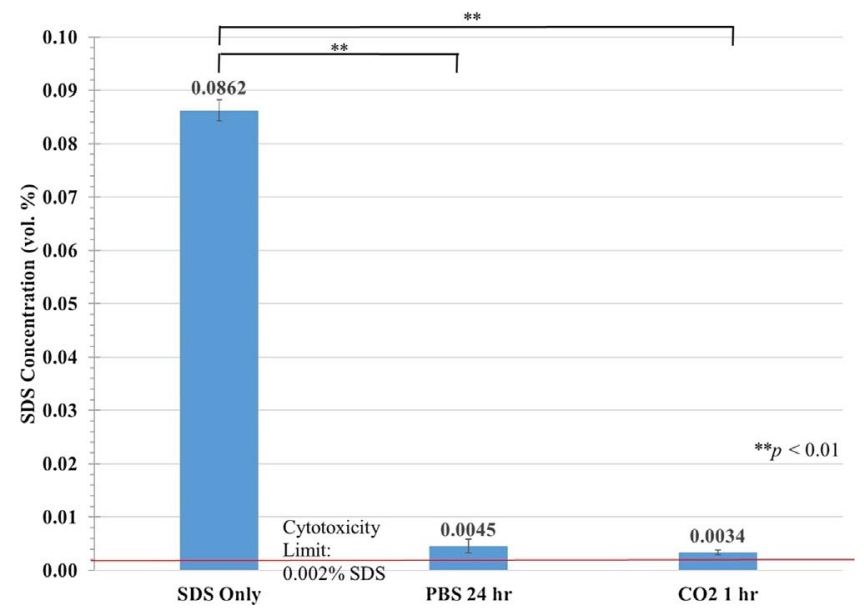

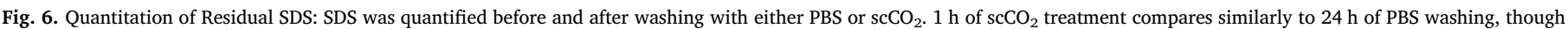
neither reduces SDS concentration below the cytotoxic level of $0.002 \%$.

Table 1

Uniaxial Ring Test Stress at $\lambda=1.1$.

${ }^{* *} p<0.01$ compared to native

\begin{tabular}{ll}
\hline Treatment & Stress (kPa) \\
\hline None (Native Tissue) & $32.7 \pm 5.4$ \\
Standard SDS & $8.9 \pm 0.9^{* * *}$ \\
scCO $_{2}$ /Ethanol & $60.6 \pm 13.5^{*}$ \\
Hybrid Treatment & $21.9 \pm 3.2^{*}$ \\
\hline
\end{tabular}

$p<0.05$ compared to native

$p<0.01$ compared to native

stiffness, likely caused by denaturation of load-bearing ECM proteins (e.g. collagen, elastin). On the other hand, treatment with $\mathrm{scCO}_{2}$ and ethanol nearly doubles the stress values and causes an increase in apparent stiffness compared to the native tissue; this is likely a result of matrix dehydration. The hybrid treatment mitigates both of these extremes because of $\mathrm{scCO}_{2}$ presaturation with water and faster SDS removal, resulting in matrices that are most similar to the native tissue. However, a statistically significant decrease in computed stress values is still observed for the hybrid treatment, showing the potency of SDS as a denaturant and emphasizing the importance of minimizing SDS exposure time and concentration during any decellularization protocol.

It should be noted that a uniaxial ring test only provides preliminary insight into mechanical property changes caused by decellularization. A uniaxial test does not reflect the loading applied to blood vessels in vivo [54], and in any case cannot be used to identify mechanical properties of an elastic, anisotropic material [55]. To identify constitutive properties of these constructs and provide a framework for comparison of mechanical properties, biaxial planar testing of flat specimens or inflation-extension of cylindrical specimens is required [56].
Further insight into the arrangement and properties of matrix proteins was obtained by staining with Masson's trichrome, Fig. 7. For the hybrid treatment (c), complete decellularization is observed along with a distribution of collagen that closely resembles the native aorta (a). SDS treatment (b) also lyses cells, but disruption of collagen is observed. This finding further indicates that less denaturing of proteins occurs during the hybrid treatment.

\section{Conclusions}

A novel method for decellularizing porcine aorta with supercritical $\mathrm{CO}_{2}$ and additives while maintaining the native hydration state was presented. First, it was demonstrated that the method reduces or eliminates the tendency of $\mathrm{scCO}_{2}$ to extract water and other volatiles that has been observed by others. The utility of the novel method has been verified by experiments on both a model hydrogel and porcine aorta, demonstrating that presaturation of $\mathrm{scCO}_{2}$ can be used to prevent undesired dehydration of biomaterials for tissue engineering.

After verifying the efficacy of presaturation, the method was used to decellularize porcine aorta. As anticipated, presaturating $\mathrm{scCO}_{2}$ with water maintained the hydration state of the matrix, even in the presence of other additives. More surprisingly, the addition of ethanol to increase $\mathrm{scCO}_{2}$ polarity did not substantially intensify the extent of decellularization, suggesting that $\mathrm{scCO}_{2}$ alone is unable to quickly penetrate the cell membrane. Next, a hybrid decellularization protocol was developed which utilized a short SDS pretreatment step before washing with $\mathrm{scCO}_{2}$ and water plus ethanol additives. This treatment proved that $\mathrm{scCO}_{2}$ can extract intracellular material if the cell membrane is lysed beforehand. Complete decellularization was achieved using this method, with a time savings of about $24 \mathrm{~h}$ and a comparable residual SDS concentration compared to the standard method.

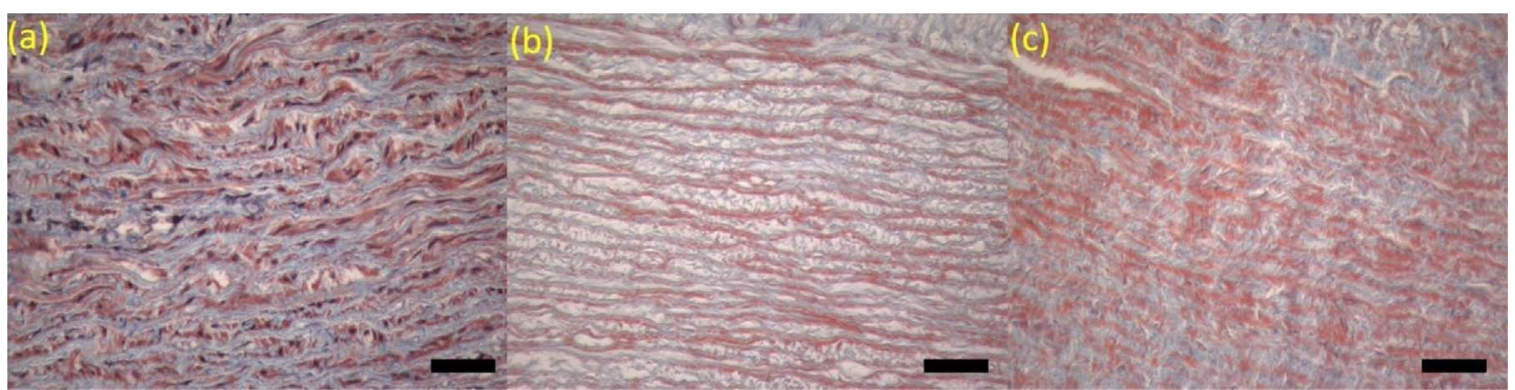

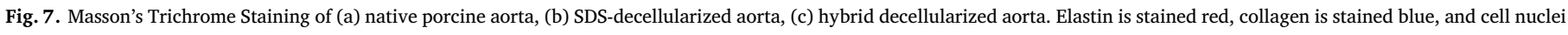
are stained black. Scale bars $=50 \mu \mathrm{m}$. (For interpretation of the references to colour in this figure legend, the reader is referred to the web version of this article.) 
Additionally, the hybrid method maintained the hydration state, matrix protein arrangement, and mechanical properties of the native tissue. Still, further study is required to determine the capabilities and limitations of this method, including bioactivity studies, treatment optimization, and scaffold testing in an animal model.

\section{Funding}

This work was partially supported by a SPARC Graduate Research Grant from the Office of the Vice President for Research at the University of South Carolina.

\section{Conflict of interest}

The authors declare that there is no conflict of interest regarding the publication of this paper.

\section{Acknowledgements}

We acknowledge the staff at the USC School of Medicine Instrument Resource Facility for their assistance in preparing histological specimens.

\section{Appendix A. Supplementary data}

Supplementary data associated with this article can be found, in the online version, at http://dx.doi.org/10.1016/j.supflu.2017.07.021.

\section{References}

[1] Introduction, Am. J. Transplant. 14 (2014).

[2] F. Berthiaume, T.J. Maguire, M.L. Yarmush, Tissue engineering and regenerative medicine: history, progress, and challenges, in: J.M. Prausnitz (Ed.), Annual Review of Chemical and Biomolecular Engineering, vol. 2, Annual Reviews, Palo Alto, 2011, pp. 403-430.

[3] B.-S. Kim, I.-K. Park, T. Hoshiba, H.-L. Jiang, Y.-J. Choi, T. Akaike, C.-S. Cho, Design of artificial extracellular matrices for tissue engineering, Prog. Polym. Sci. 36 (2011) 238-268.

[4] J.E. Reing, L. Zhang, J. Myers-Irvin, K.E. Cordero, D.O. Freytes, E. Heber-Katz, K. Bedelbaeva, D. McIntosh, A. Dewilde, S.J. Braunhut, S.F. Badylak, Degradation products of extracellular matrix affect cell migration and proliferation, Tissue Eng. Part A 15 (2009) 605-614.

[5] B.N. Brown, S.F. Badylak, Extracellular matrix as an inductive scaffold for functional tissue reconstruction, Transl. Res. 163 (2014) 268-285.

[6] R.A. Hortensius, B.A.C. Harley, Naturally derived biomaterials for addressing inflammation in tissue regeneration, Exp. Biol. Med. 241 (2016) 1015-1024.

[7] A. Petrosyan, S. Da Sacco, N. Tripuraneni, U. Kreuser, M. Lavarreda-Pearce, R. Tamburrini, R.E. De Filippo, G. Orlando, P. Cravedi, L. Perin, A step towards clinical application of acellular matrix: a clue from macrophage polarization, Matrix Biol. 57-58 (2017) 334-346.

[8] N. Syazwani, A. Azhim, Y. Morimoto, K.S. Furukawa, T. Ushida, Decellularization of aorta tissue using sonication treatment as potential scaffold for vascular tissue engineering, J. Med. Biol. Eng. 35 (2015) 258-269.

[9] H.W. Xu, B.S. Xu, Q. Yang, X.L. Li, X.L. Ma, Q. Xia, Y. Zhang, C.Q. Zhang, Y.H. Wu, Y.Y. Zhang, Comparison of decellularization protocols for preparing a decellularized porcine annulus fibrosus scaffold, PLoS One 9 (2014).

[10] T.C. Evaristo, F.C.M. da CruzAlves, A. Moroz, W. Mion, M.J. Acorci-Valerio, S.L. Felisbino, R. Rossi-Ferreira, R.L. Ruiz, E. Deffune, Light-emitting diode effects on combined decellularization of tracheae. A novel approach to obtain biological scaffolds, Acta Cir. Bras. 29 (2014) 485-492.

[11] J. Kundu, A. Michaelson, K. Talbot, P. Baranov, M.J. Young, R.L. Carrier, Decellularized retinal matrix: natural platforms for human retinal progenitor cell culture, Acta Biomater. 31 (2016) 61-70.

[12] G. Jones, A. Herbert, H. Berry, J.H. Edwards, J. Fisher, E. Ingham, Decellularization and characterization of porcine superflexor tendon: a potential anterior cruciate ligament replacement, Tissue Eng. Part A 23 (2017) 124-134.

[13] T.J. Keane, I.T. Swinehart, S.F. Badylak, Methods of tissue decellularization used for preparation of biologic scaffolds and in vivo relevance, Methods 84 (2015) 25-34.

[14] L.N. Sierad, E.L. Shaw, A. Bina, B. Brazile, N. Rierson, S.S. Patnaik, A. Kennamer, R. Odum, O. Cotoi, P. Terezia, K. Branzaniuc, H. Smallwood, R. Deac, I. Egyed, Z. Pavai, A. Szanto, L. Harceaga, H. Suciu, V. Raicea, P. Olah, A. Simionescu, J. Liao, I. Movileanu, M. Harpa, D.T. Simionescu, Functional heart valve scaffolds obtained by complete decellularization of porcine aortic roots in a novel differential pressure gradient perfusion system, Tissue Eng. Part C-Methods 21 (2015) 1284-1296.

[15] R. Ackbar, H. Ainoedhofer, M. Gugatschka, A.K. Saxena, Decellularized ovine esophageal mucosa for esophageal tissue engineering, Technol. Health Care 20 (2012)
215-223.

[16] M.A. McHugh, V.J. Krukonis, Supercritical Fluid Extraction: Principles and Practice, Butterworth, Stoneham, Mass, 1994.

[17] X. Liu, D.L. Yang, J.J. Liu, K. Xu, G.H. Wu, Modeling of supercritical fluid extraction of flavonoids from Calycopteris floribunda leaves, Chem. Pap. 68 (2014) 316-323.

[18] H. Bagheri, M.Y.B. Manap, Z. Solati, Response surface methodology applied to supercritical carbon dioxide extraction of Piper nigrum L. essential oil, LWT-Food Sci. Technol. 57 (2014) 149-155.

[19] G. Ferrentino, S. Spilimbergo, High pressure carbon dioxide pasteurization of solid foods: current knowledge and future outlooks, Trends Food Sci. Technol. 22 (2011) 427-441.

[20] G. Ferrentino, A. Belscak-Cvitanovic, D. Komes, S. Spilimbergo, Quality attributes of fresh-cut coconut after supercritical carbon dioxide pasteurization, J. Chem. 2013 (2013) 9, http://dx.doi.org/10.1155/2013/703057 Article ID 703057.

[21] G. Ferrentino, S. Balzan, S. Spilimbergo, On-line color monitoring of solid foods during supercritical $\mathrm{CO}_{2}$ pasteurization, J. Food Eng. 110 (2012) 80-85.

[22] A. Jimenez, J. Zhang, M.A. Matthews, Evaluation of $\mathrm{CO}_{2}$-based cold sterilization of a model hydrogel, Biotechnol. Bioeng. 101 (2008) 1344-1352.

[23] P.J. Tarafa, A. Jimenez, J.A. Zhang, M.A. Matthews, Compressed carbon dioxide $\left(\mathrm{CO}_{2}\right)$ for decontamination of biomaterials and tissue scaffolds, J. Supercrit. Fluids 53 (2010) 192-199.

[24] J. Zhang, T.A. Davis, M.A. Matthews, M.J. Drews, M. LaBerge, Y.H.H. An, Sterilization using high-pressure carbon dioxide, J. Supercrit. Fluids 38 (2006) $354-372$.

[25] J.L. Wehmeyer, S. Natesan, R.J. Christy, Development of a sterile amniotic membrane tissue graft using supercritical carbon dioxide, Tissue Eng. Part C-Methods 21 (2015) 649-659.

[26] J.L. Balestrini, A. Liu, A.L. Gard, J. Huie, K.M.S. Blatt, J. Schwan, L.P. Zhao, T.J. Broekelmann, R.P. Mecham, E.C. Wilcox, L.E. Niklason, Sterilization of lung matrices by supercritical carbon dioxide, Tissue Eng. Part C-Methods 22 (2016) 260-269.

[27] J.J.A. Barry, S.N. Nazhat, F. Rose, A.H. Hainsworth, C.A. Scotchford, S.M. Howdle, Supercritical carbon dioxide foaming of elastomer/heterocyclic methacrylate blends as scaffolds for tissue engineering, J. Mater. Chem. 15 (2005) 4881-4888.

[28] M. Floren, S. Spilimbergo, A. Motta, C. Migliaresi, Porous poly(D,L-lactic acid) foams with tunable structure and mechanical anisotropy prepared by supercritical carbon dioxide, J. Biomed. Mater. Res. Part B-Appl. Biomater. 99B (2011) 338-349.

[29] H.Y. Tai, M.L. Mather, D. Howard, W.X. Wang, L.J. White, J.A. Crowe, S.P. Morgan, A. Chandra, D.J. Williams, S.M. Howdle, K.M. Shakesheff, Control of pore size and structure of tissue engineering scaffolds produced by supercritical fluid processing, Eur. Cells Mater. 14 (2007) 64-76.

[30] A.R.C. Duarte, S.G. Caridade, J.F. Mano, R.L. Reis, Processing of novel bioactive polymeric matrixes for tissue engineering using supercritical fluid technology, Mater. Sci. Eng. C-Mater. Biol. Appl. 29 (2009) 2110-2115.

[31] A. Zambon, M. Vetralla, L. Urbani, M.F. Pantano, G. Ferrentino, M. Pozzobon, N.M. Pugno, P. De Coppi, N. Elvassore, S. Spilimbergo, Dry acellular oesophageal matrix prepared by supercritical carbon dioxide, J. Supercrit. Fluids 115 (2016) 33-41.

[32] K. Sawada, D. Terada, T. Yamaoka, S. Kitamura, T. Fujisato, Cell removal with supercritical carbon dioxide for acellular artificial tissue, J. Chem. Technol. Biotechnol. 83 (2008) 943-949.

[33] D.I. Abramson, Blood Vessels and Lymphatics, Academic Press, New York, 1962.

[34] S.B. Lumpkins, N. Pierre, P.S. McFetridge, A mechanical evaluation of three decellularization methods in the design of a xenogeneic scaffold for tissue engineering the temporomandibular joint disc, Acta Biomater. 4 (2008) 808-816.

[35] E. Sachlos, D.A. Wahl, J.T. Triffitt, J.T. Czernuszka, The impact of critical point drying with liquid carbon dioxide on collagen-hydroxyapatite composite scaffolds, Acta Biomater. 4 (2008) 1322-1331.

[36] P.J. Shah, Z. Wu, A.M. Sarangan, Effects of $\mathrm{CO}_{2}$ critical point drying on nanostructured $\mathrm{SiO}_{2}$ thin films after liquid exposure, Thin Solid Films 527 (2013) 344-348.

[37] H. Halbritter, Preparing living pollen material for scanning electron microscopy using 2,2-dimethoxypropane (DMP) and critical-point drying, Biotech. Histochem. 73 (1998) $137-143$

[38] S. Funamoto, K. Nam, T. Kimura, A. Murakoshi, Y. Hashimoto, K. Niwaya, S. Kitamura, T. Fujisato, A. Kishida, The use of high-hydrostatic pressure treatment to decellularize blood vessels, Biomaterials 31 (2010) 3590-3595.

[39] W.O. Twal, S.C. Klatt, K. Harikrishnan, E. Gerges, M.A. Cooley, T.C. Trusk, B. Zhou, M.G. Gabr, T. Shazly, S.M. Lessner, R.R. Markwald, W.S. Argraves, Cellularized microcarriers as adhesive building blocks for fabrication of tubular tissue constructs, Ann. Biomed. Eng. 42 (2014) 1470-1481.

[40] E.M. Ahmed, Hydrogel preparation, characterization, and applications: a review, J. Adv. Res. 6 (2015) 105-121.

[41] J.W. Lee, E. Fukusaki, T. Bamba, Application of supercritical fluid carbon dioxide to the extraction and analysis of lipids, Bioanalysis 4 (2012) 2413-2422.

[42] P.M. Crapo, T.W. Gilbert, S.F. Badylak, An overview of tissue and whole organ decellularization processes, Biomaterials 32 (2011) 3233-3243.

[43] T.W. Gilbert, T.L. Sellaro, S.F. Badylak, Decellularization of tissues and organs, Biomaterials 27 (2006) 3675-3683.

[44] D.M. Faulk, C.A. Carruthers, H.J. Warner, C.R. Kramer, J.E. Reing, L. Zhang, A. D'Amore, S.F. Badylak, The effect of detergents on the basement membrane complex of a biologic scaffold material, Acta Biomater. 10 (2014) 183-193.

[45] L. Flynn, J.L. Semple, K.A. Woodhouse, Decellularized placental matrices for adipose tissue engineering, J. Biomed. Mater. Res. A 79A (2006) 359-369.

[46] A.N. Sabirzyanov, A.P. Il'in, A.R. Akhunov, F.M. Gumerov, Solubility of water in supercritical carbon dioxide, High Temp. 40 (2002) 203-206. 
[47] J.C. Liu, B.X. Han, H.L. Zhang, G.Z. Li, X.G. Zhang, J. Wang, B.Z. Dong, Formation of water-in- $\mathrm{CO}_{2}$ microemulsions with non-fluorous surfactant Ls-54 and solubilization of biomacromolecules, Chem.- Eur. J. 8 (2002) 1356-1360.

[48] P.J. Tarafa, E. Williams, S. Panvelker, J.Z. Zhang, M.A. Matthews, Removing endotoxin from metallic biomaterials with compressed carbon dioxide-based mixtures, J. Supercrit. Fluids 55 (2011) 1052-1058.

[49] P.J. Tarafa, M.A. Matthews, Phase equilibrium for surfactant Ls-54 in liquid $\mathrm{CO}_{2}$ with water and solubility estimation using the Peng-Robinson equation of state, Fluid Phase Equilib. 298 (2010) 212-218.

[50] B. Zvarova, F.E. Uhl, J.J. Uriarte, Z.D. Borg, A.L. Coffey, N.R. Bonenfant, D.J. Weiss, D.E. Wagner, Residual detergent detection method for nondestructive cytocompatibility evaluation of decellularized whole lung scaffolds, Tissue Eng. Part CMethods 22 (2016) 418-428.

[51] S. Cebotari, I. Tudorache, T. Jaekel, A. Hilfiker, S. Dorfman, W. Ternes, A. Haverich, A. Lichtenberg, Detergent decellularization of heart valves for tissue engineering: toxicological effects of residual detergents on human endothelial cells, Artif. Organs 34 (2010) 206-210

[52] R. Joshi, G.D.K. Babu, A. Gulati, Effect of decaffeination conditions on quality parameters of Kangra orthodox black tea, Food Res. Int. 53 (2013) 693-703.

[53] M.R. Roach, A.C. Burton, The reason for the shape of the distensibility curves of arteries, Can. J. Biochem. Physiol. 35 (1957) 681-690.

[54] R.A. Macrae, K. Miller, B.J. Doyle, Methods in mechanical testing of arterial tissue: a review, Strain 52 (2016) 380-399.

[55] T. Shazly, A. Rachev, S. Lessner, W.S. Argraves, J. Ferdous, B. Zhou, A.M. Moreira, M. Sutton, On the uniaxial ring test of tissue engineered constructs, Exp. Mech. 55 (2015) 41-51.

[56] S.R. de Galarreta, R. Anton, A. Cazon, G.S. Larraona, E.A. Finol, Anisotropic abdominal aortic aneurysm replicas with biaxial material characterization, Med. Eng. Phys. 38 (2016) 1505-1512. 